Dunamis: Jurnal Teologi dan Pendidikan Kristiani

Volume 4, Nomor 2 (April 2020)

ISSN 2541-3937 (print), 2541-3945 (online)

http://www.sttintheos.ac.id/e-journal/index.php/dunamis

DOI: $10.30648 /$ dun.v4i2.210

Submitted: 7 Agustus 2019

Accepted: 3 November 2019

Published: 16 Maret 2020

\title{
Peran Pelayanan Pastoral bagi Ibu yang Mengalami Kekerasan Dalam Rumah Tangga
}

\author{
Derselli P. Silitonga \\ Program Studi Magister Sosiologi Agama, Universitas Kristen Satya Wacana \\ pranithaderselli@gmail.com
}

\begin{abstract}
Domestic violence is an issue that is considered a private household problem so it cannot merely be handled by the government or the authorities. For this reason, this study aimed to describe the important role of pastoral care in dealing with domestic violence. The method used in this research was descriptive qualitative research method. Data was collected through observation, interview and literature study and analyzed in depth and described descriptively. The result was that pastoral care is an effective way to deal with the problem of domestic violence by not bringing it into the public sphere and creating peace between husband and wife.
\end{abstract}

Keywords: pastoral ministry; domestic violence; housewife

\begin{abstract}
Abstrak
Kekerasan dalam rumah tangga merupakan isu yang dianggap sebagai persoalan privat rumah tangga sehingga tidak begitu saja dapat ditangani oleh pemerintah atau pihak yang berwajib. Untuk itu, penelitian ini bertujuan untuk memberikan gambaran pentingnya peran pelayanan pastoral dalam menangani masalah kekerasan dalam rumah tangga. Metode yang digunakan dalam penelitian ini adalah metode penelitian deskriptif kualitatif. Data-data dikumpulkan melalui observasi, wawancara dan studi kepustakaan serta dianalisa secara mendalam dan diuraikan secara deskriptif. Hasilnya adalah pelayanan pastoral merupakan cara yang efektif untuk menangani masalah kekerasan dalam rumah tangga oleh karena tidak membawanya ke ranah publik dan menciptakan perdamaian di antara suami istri.
\end{abstract}

Kata Kunci: pelayanan pastoral; kekerasan dalam rumah tangga; ibu rumah tangga 


\section{PENDAHULUAN}

Menurut Undang-Undang No 23 tahun 2004 Tentang Penghapusan Kekerasan Dalam Rumah Tangga, Kekerasan Dalam Rumah Tangga (KDRT) didefinisikan sebagai setiap perbuatan terhadap seseorang terutama perempuan, yang berakibat timbulnya kesengsaraan atau penderitaan secara fisik, seksual, psikologis, dan/atau penelantaran rumah tangga termasuk ancaman untuk melakukan perbuatan pemaksaan, atau perampasan kemerdekaan secara melawan hukum dalam lingkup rumah tangga. Kekerasan yang sering terjadi dalam rumah tangga berupa kekerasan fisik dan psikis. Kekerasan fisik adalah kekerasan berupa tindakan yang bentuknya memukul, menampar, menjambak, menendang, melukai dengan alat tumpul dan tajam bahkan membunuh. Sedangkan kekerasan psikis berupa cercaan terhadap istri, pelecehan, memaki dengan sebutan-sebutan yang salah misalnya lonthe (pelacur). ${ }^{1}$ Maidin Gultom dalam bukunya menjelaskan bentuk-bentuk kekerasan dalam rumah tangga yang sering terjadi adalah sebagai berikut: ${ }^{2}$

1. Phisykal abuse (kekerasan fisik) menunjukkan pada cedera yang ditemukan, bukan karena suatu kecelakaan tetapi cedera tersebut adalah hasil dari

\footnotetext{
${ }^{1}$ A. Nunuk Prasetyo Murniati, Gerakan Anti Kekerasan Perempuan (Yogyakarta: Kanisius, 1998), 24.
}

pemukulan dengan benda. Bentukbentuk kekerasan fisik dapat berupa jambakan, pukulan dengan alat tajam maupun alat tumpul, ditampar dan tindakan lain yang dapat melukai fisik seseorang.

2. Emotional abuse (kekerasan emosional/psikis) adalah perbuatan yang mengakibatkan ketakutan, hilangnya rasa percaya diri, hilangnya kemampuan untuk bertindak, rasa tidak berdaya atau penderitaan psikis berat pada seseorang. Misalnya tidak mempedulikan, mendiskriminasikan, meneror, mengancam, atau secara te-rangterangan menolak seseorang, di-caci dan lain sebagainya.

3. Sexsual abuse (kekerasan seksual) adalah pemaksaan hubungan seksual yang dilakukan terhadap orang yang menetap dalam rumah tangga. Kekerasan seksual menunjuk kepada setiap aktivitas seksual, misalnya pemerkosaan kepada seseorang dan pemaksa-an hubungan seks kepada istri di dalam rumah tangga.

4. Penelantaran rumah tangga adalah perbuatan setiap orang yang menelantarkan orang dalam lingkup rumah tangganya, padahal menurut

${ }^{2}$ Maidin Gultom, Perlindungan Hukum Terhadap Anak Dan Perempuan (Bandung: Refika Aditama, 2012), 16. 
hukum yang berlaku ia wajib memberikan kehidupan, perawatan, atau pendidikan kepada orang tersebut. Contohnya: tidak melakukan pekerjaan sehingga kebutuhan rumah tangga tidak terpenuhi, tidak memberikan perhatian kepada anak baik secara jasmani dan emosi.

Berdasarkan Catatan Tahunan (CATAHU) oleh Komisi Nasional Anti Kekerasan Terhadap Perempuan (Komnas Perempuan) pada tahun 2017 kasus kekerasan terhadap perempuan meningkat $74 \%$ dari tahun 2016. Berdasarkan data tersebut jenis kekerasan terhadap perempuan yang paling menonjol adalah dalam ranah KDRT (ranah personal), yang mencapai $71 \%$ (9.609 orang) dan 723 berakhir dengan perceraian. Situasi ini tampak dari penelitian yang dilakukan oleh Rendi Amanda di kelurahan Umban Sari Kecamatan Rumbai Kota Pekanbaru yang menunjukkan bahwa kekerasan dalam rumah tangga meliputi kekerasan fisik yang mencapai $82,7 \%$; kekerasan psikis mencapai 78,0\%; dan penelantaran rumah tangga mencapai $82,1 \% .^{3}$ Senada dengan hal tersebut Mery Ramadhani dan Fitri Yuliani memperlihat-

\footnotetext{
3 Rendi Amanda Ramadhan And Nurhamlin, "Pengaruh Kekerasan Dalam Rumah Tangga (KDRT) Terhadap Tingkat Keharmonisan Dalam Keluarga Di Kelurahan Umban Sari Kecamatan Rumbai Kota Pekanbaru," Jurnal Online Mahasiswa (JOM) Bidang Ilmu Sosial dan Ilmu Politik 5, no. 1 (2018): 1-15, accessed March 3, 2020,
}

kan bahwa kekerasan dalam rumah tangga cenderung dialami oleh istri atau pun ibu rumah tangga dan yang menjadi pelakunya adalah suaminya sendiri. ${ }^{4}$

Hal yang serupa terjadi juga di desa Onantukka Kecamatan Sipahutar yang menjelaskan hampir setengah dari jumlah keseluruhan penduduk desa mengalami kekerasan dalam rumah tangga baik secara fisik maupun psikis. Dari 384 keluarga, 5 diantaranya mengalami kekerasan fisik dan 110 mengalami kekerasan psikis berupa penelantaran keluarga yang dilakukan oleh suami. Umumnya yang mengalami kekerasan dalam rumah tangga di desa Onantukka adalah ibu rumah tangga. Situasi ini jarang terkuak karena ibu yang menjadi korban menganggap situasi tersebut adalah bagian privat dari keluarga yang tidak perlu diketahui oleh lingkungan sekitar. Dengan situasi tersebut, sebagian ibu yang mengalami kekerasan dalam rumah tangga tidak mau melaporkan kepada pihak yang berwajib (menempuh jalur hukum). Hal ini bukan karena istri/ibu rumah tangga nyaman dengan situasi tersebut akan tetapi bagi sang istri lebih memalukan ketika persoalan itu sendiri sampai pada penanganan hukum.

https://jom.unri.ac.id/index.php/JOMFSIP/article/vi ew/17259.

4 Mery Ramadani and Fitri Yuliani, "Kekerasan Dalam Rumah Tangga (KDRT) Sebagai Salah Satu Isu Kesehatan Masyarakat Secara Global," Jurnal Kesehatan Masyarakat Andalas 9, no. 2 (August 30, 2017): 80. 
Di sisi lain, program pemerintah dengan adanya UUPKDRT tidak dapat menjangkau kekerasan yang dialami oleh ibu rumah tangga di desa Onantukka. Oleh karena itu, penulis melihat gereja sebagai lembaga kasih memiliki peran penting untuk memberikan perhatian atau pun kepedulian kepada ibu yang mengalami kekerasan dalam rumah tangga.

Berdasarkan beberapa kajian tentang kekerasan dalam rumah tangga yang dikemukakan di atas, penulis melihat bahwa pada kajian sebelumnya belum ada yang memaparkan keterlibatan gereja dalam upaya pencegahan kekerasan dalam rumah tangga. Oleh karena itu, yang menjadi fokus tulisan ini adalah pelayanan pastoral terhadap ibu yang mengalami kekerasan dalam rumah tangga. Tujuannya adalah untuk memberikan gambaran pentingnya pelayanan pastoral dalam penanganan persoalan KDRT.

\section{METODE PENELITIAN}

Metode yang digunakan dalam penelitian ini adalah metode penelitian kualitatif. Pendekatan ini dipilih oleh karena pendekatan ini sesuai dengan karakterisktik lingkungan alamiah (natural setting) yang mana peneliti langsung berhadapan secara langsung dengan partisipaan untuk mempe- roleh data lapangan. ${ }^{5}$ Teknik pengumpulan data dilakukan melalui observasi-partisipasi, wawancara dan studi pustaka. Observasi-partisipatif dilakukan dengan cara melakukan pengamatan terhadap permasalahan kekerasan yang terjadi. Untuk mengetahui peristiwa kekerasan yang dialami ibu rumah tangga, maka penulis melakukan wawancara terhadap 11 orang partisipan. Empat diantaranya ibu yang menjadi korban kekerasan dalam rumah tangga; pelaku (suami) kekerasan dalam rumah tangga sebanyak 3 orang; dan orang-orang yang pernah terlibat dalam penanganan kasus kekerasan dalam rumah tangga sebanyak 4 orang. Lokasi penelitian adalah di Desa Onantukka Aeknauli IV Kecamatan Sipahutar Kabupaten Tapanuli Utara Provinsi Sumatera Utara.

Langkah-langkah yang dilakukan dalam kajian ini yang pertama dengan melakukan analisis terhadap kasus-kasus KDRT yang terjadi di desa Onantukka dan mengkajinya dengan beberapa literatur maupun hasil penelitian lainnya untuk mendapatkan gambaran permasalahan yang sebenarnya. Langkah selanjutnya adalah memaparkan peran pelayanan pastoral gereja sebagai salah satu solusi dalam menangani masalah KDRT tersebut.

\footnotetext{
${ }^{5}$ John W. Creswell, Research Design: Pendekatan Kualitatif, Kuantitatif, Dan Mixed (Yogyakarta: Pustaka Pelajar, 2012), 247.
} 


\section{HASIL DAN PEMBAHASAN}

\section{Analisis Masalah KDRT}

Faktor-faktor yang memicu terjadinya kekerasan dalam rumah tangga adalah salah satu merasa paling dominan atau pun superior dalam keluarga. Laki-laki/ suami dalam keluarga dianggap lebih kuat dan memiliki otoritas yang tinggi dibanding perempuan. Situasi ini dipengaruhi peran gender, di mana laki-laki yang bersifat maskulin dianggap gagah, kuat, berani dan karakter perempuan feminin yang dianggap lemah, lembut dan penurut, sehingga mempengaruhi laki-laki untuk bertindak semena-mena terhadap perempuan. ${ }^{6} \mathrm{~W}$. Ngir berpendapat bahwa faktor yang memicu kekerasan dalam rumah tangga adalah (1) Faktor psikologis, yaitu kurang mendapatkan dukungan emosional seperti kasih sayang dari salah satu pihak baik istri maupun suami. Apabila suami atau pun istri tidak mendapatkan kasih sayang dalam rumah tangga cenderung akan mengakibatkan timbulnya kekerasan dalam rumah tangga; (2) Faktor ekonomi, yang mana pengeluaran dan pendapatan tidak seimbang dalam rumah tangga, dan kemudian sebagai pelampiasannya adalah tindakan

6 Suryati, Kekerasan Dalam Rumah Tangga (Parapat: KSPPM, 2013), 1.

${ }^{7}$ Desefention W. Ngir, 10 Kebutuhan Utama Dalam Pernikahan (Bandung: Kalam Hidup, 2014), 31-35.

${ }^{8}$ Ramadani and Yuliani, "Kekerasan Dalam Rumah Tangga (KDRT) Sebagai Salah Satu Isu Kesehatan Masyarakat Secara Global.” memukul atau mencaci istri (ketika istri meminta uang kepada suami untuk memenuhi kebutuhan rumah tangga); (3) Tidak adanya keterbukaan atau pun kejujuran dalam rumah tangga. Hal ini tercipta ketika tidak ada komunikasi yang baik antara pasangan suami istri. ${ }^{7}$

Faktor lainnya yang menyebabkan KDRT adalah karena faktor ekonomi dan juga pelaku kekerasan atau suami cenderung mengalami kekerasan pada masa kecil yang tidak mengalami penanganan sehingga ketika sudah berkeluarga suami melakukan hal yang sama terhadap istrinya. ${ }^{8}$ Faktor lain yang menyebabkan kekerasan dalam rumah tangga adalah faktor cemburu dan perselingkuhan yang bersumber dari sosial media sebagaimana penelitian yang dilakukan oleh Dewi Indah Susanty dan Julqurniati di kota Larantuka Kabupaten Flores Timur menunjukkan hampir $30 \%$ penduduk perempuan mengalami kekerasan dalam rumah tangga karena faktor cemburu dan perselingkuhan. ${ }^{9}$ Faktor yang berbeda yang ditemukan oleh Pustikasari dalam penelitiannya menjelaskan bahwa faktor yang memicu kekerasan dalam rumah tangga adalah faktor pendidikan, dimana perem-

9 Dewi Indah Susanty and Nur Julqurniati, "Kekerasan Terhadap Perempuan Dalam Rumah Tangga Di Flores Timur," Sosio Konsepsia 8, no. 2 (July 16, 2019): 139-156. 
puan yang mempunyai suami berpendidikan rendah mempunyai resiko dua kali lipat mengalami kekerasan dalam rumah tangga. ${ }^{10}$

Ruang lingkup kekerasan terhadap perempuan dapat dikelompokkan dalam tiga kelompok yaitu kekerasan wilayah domestik, kekerasan dalam wilayah publik, dan kekerasan yang dilakukan oleh negara (diwakili militer). ${ }^{11}$ Kekerasan yang dialami ibu di desa Onantukka merupakan kekerasan yang termasuk dalam ruang lingkup domestik yang mana pelaku masih memiliki hubungan yang terikat keluarga dengan korban. Kekerasan ini terjadi diakibatkan oleh berbagai sebab. Hal ini tampak dari penjelasan partisipan yang mengemukakan kekerasan dalam rumah tangga terjadi karena tidak mendapatkan penghasilan yang cukup untuk memenuhi kebutuhan rumah tangga. Sebagaimana pengalamannya ketika meminta uang kepada suami untuk memenuhi kebutuhan keluarga, kebutuhan sekolah anak-anak dan lain sebagainya, tetapi justru mendapatkan respon yang kasar dari suami, dan bahkan melemparkan barang-barang tertentu yang mengakibatkan tubuhnya mengalami luka.

\footnotetext{
${ }^{10}$ Fini Fajrini, Rr Arum Ariasih, and Noor Latifah A, "Determinan Sikap Tindak Kekerasan Dalam Rumah Tangga Di Provinsi Banten," Aspirasi: Jurnal Masalah-Masalah Sosial 9, no. 2 (2018): 173-189, accessed March 5, 2020, http://jurnal.dpr.go.id/index.php/aspirasi/article/vie w/1113.
}

Keadaan tersebut membuat korban/istri takut untuk berbicara dengan suami dan memilih diam dan melakukan perkerjaan seperti menanam sayur dan menjualnya sehingga dapat mencukupi kebutuhan rumah tangga. Situasi ini awalnya berjalan dengan baik dan keadaan keluarga baik, tetapi karena kesanggupan istri dalam melakukan pekerjaan tersebut membuat suami tidak melakukan pekerjaan dan hanya nongkrong di lapo tuak (warung). Hal yang dilakukan adalah bermain judi dan minum tuak (tuak=minuman khas Batak Toba) $)^{12}$.

Partisipan yang lain menjelaskan bahwa pemicu kekerasan dalam rumah tangganya disebabkan karena kebiasaan suami yang tidak pernah manghalaputi ulaon (mengerjakan pekerjaannya) seperti bertani dengan serius. Padahal pekerjaan utama mereka adalah bertani. Ketika istri mengingatkan suaminya dan mengajak supaya bersama-sama melakukan pekerjaan tani. Namun yang didapatkan adalah respon suami yang kasar dan mengatakan "tidak ada hakmu untuk mengatur hidup aku, aku yang mengatur kamu karena saya pemimpin dalam rumah tangga." Atau dengan ung-

11 M. Asasul Muttaqin, Ali Murtadho, and Anila Umriana, "Bimbingan Konseling Bagi Perempuan Korban Kekerasan Dalam Rumah Tangga Di LrcKjham Semarang," Sawwa: Jurnal Studi Gender 11, no. 2 (June 12, 2017): 177.

12 Wawancara dengan ibu TS yang bekerja sebagai ibu rumah tangga dan memiliki anak 4 orang. 
kapan "nanti aku akan menyusul, masih ada yang harus aku kerjakan." Sementara yang sedang dikerjakannya adalah nongkrong di lapo dan pergi bersama dengan temannya memancing ikan. Pada akhirnya, yang menjadi tulang punggung dalam keluarga itu adalah ibu rumah tangga. Kebiasaan suaminya adalah meminta uang kepada istri dengan ancaman dan paksaan untuk dipergunakan membeli rokok atau pun alat pancing. ${ }^{13}$

Kasus KRDT lainnya dialami oleh seorang ibu yang berinisial XS. Ibu tersebut menjelaskan kekerasan dalam rumah tangga sering terjadi hanya karena masalah sepele. Hal sepele yang dimaksud adalah ketika sang istri mengajak suami untuk mengikuti partangiangan (ibadah kelompok) atau ibadah mengikuti ibadah setiap hari minggu. Suami merespon dengan kasar dan mengatakan "kamu tidak perlu mengajak aku ke gereja. Tidak ada gunanya pergi ke gereja kalau keluarga di rumah saja tidak diperhatikan dan kalau kejujuran tidak ada dalam rumah tangga." Pernyataan suami secara tidak langsung menyinggung perasaan istri yang mengakibatkan ada respon negatif dari istri. Akhirnya suami tidak dapat mengontrol emosinya dan melakukan kekerasan terhadap istri dengan tindakan me-

13 Wawancara dengan ibu AF (memiliki 2 anak) dan SS (memiliki 3 anak) bekerja sebagai ibu rumah tangga mukul dan mengatakan "pergi dari rumah ini." Mau tidak mau, untuk menghindari pukulan dari suami, istri pergi dan meninggalkan rumah sementara waktu. Situasi ini membuat suami dan istri tidak berkomunikasi antara satu dengan yang lain. Akibatnya, suami tidak nyaman untuk tinggal di rumah dan melampiaskan ketidaknyamanannya untuk minum tuak di lapo tuak dan jarang melakukan pekerjaan untuk mencukupi kebutuhan rumah tangga. Sementara alasan istri mengajak suami ke gereja adalah karena istri merasa malu mendengar ocehan dari masyarakat sekitar yang mengatakan bahwa keluarga mereka kurang bersyukur (suami tidak pernah gereja). Hal ini terungkap karena keluarga XS termasuk orang yang bisa mencukupi kebutuhan rumah tangga bahkan keluarga mereka sering meminjamkan uang kepada orang yang membutuhkan tanpa membuat bunga uang tetapi keluarga tidak pernah menerima partangiangan dilakukan di rumahnya dan suami sangat jarang untuk bergabung dengan kegiatan paradaton (acara nikah dan pesta lain sesuai dengan adat Batak). ${ }^{14}$

Berbeda dengan pandangan suami/ pelaku kekerasan dalam rumah tangga. Bagi mereka tindakan yang mereka lakukan

14 Wawancara dengan ibu XS sebagai ibu rumah tangga dan memiliki anak 5 
terhadap istri bukanlah tindakan kekerasan tetapi karena ada kehilafan. Yang dikategorikan sebagai tindakan kekerasan menurut mereka adalah berupa tindakan pembunuhan yang dilakukan kepada istri atau anak atau terhadap orang lain. Persoalan caci maki dalam keluarga adalah hal yang biasa dan tidak perlu dipersoalkan. Nyatanya, sampai sekarang istri menerima perlakuan tersebut, dan itu adalah hal yang wajar karena firman Tuhan juga mengatakan hal demikian, istri harus tunduk kepada suami karena suami adalah kepala rumah tangga atau pemimpin dalam rumah tangga tersebut. ${ }^{15}$

Pandangan yang berbeda yang dikemukakan oleh AS/ suami XS. Dia melakukan tindakan kekerasan dalam rumah tangga di luar kesadarannya. Dia mengakui bahwa yang dilakukannya adalah salah dan tidak pantas karena istrinya pernah terluka secara fisik karena dia memukulnya. Yang memicu suami untuk melakukan pukulan terhadap istri di dalam rumah tangga karena pengalaman suami yang kurang dihargai sebagai kepala keluarga. Contohnya, “istri saya pernah mempermalukan saya di depan umum" dan memang situasi tersebut lewat begitu saja, dan dia tidak mau minta maaf kepada saya sebagai suaminya. Di sisi lain, "keterbukaan dan kejujuran dalam rumah

\footnotetext{
${ }^{15}$ Wawancara dengan bapak ST (suami AF) dan BS (suami SS)
}

tangga kami tidak ada. Keterbukaan yang saya maksud adalah transparansi tentang keuangan. Yang memegang dan mengatur uang tentu istri saya, saya tidak keberatan akan hal tersebut, tetapi yang terpenting bagi saya, seharusnya istri memberitahukan kemana uang itu dipergunakan. Jadi ketika dia mengeluh tentang keuangan sudah menipis, saya tidak terkkejut. Artinya ada komunikasi itu tandanya bahwa saya dihargai sebagai kepala keluarga."16

Berdasarkan keterangan yang disampaikan oleh partisipan di atas, penulis dapat menganalisis bahwa faktor yang menyebabkan kekerasan yang dialami ibu rumah tangga di desa Onantukka tidak jauh berbeda dengan yang dikemukakan oleh Suryati dan W.Ngir. Adapun faktor yang menyebabkan kekerasan dalam rumah tangga di desa Onantukka adalah (1) faktor gender, di mana suami menganggap dirinya paling dominan dan lebih kuat sedangkan istri lemah dan tugasnya adalah hanya sebatas ibu rumah tangga yang harus menuruti perintah dan melayani suami sebagai kepala rumah tangga (tampak dari respon bapak ST dan BS); (2) ekonomi lemah, yang mana pengeluaran lebih besar dari penghasilan suami yang kecil. Faktor ini mengakibatkan emosi suami tidak dapat terkontrol ketika istri membutuhkan uang untuk memenuhi

\footnotetext{
${ }^{16}$ Wawancara dengan AS/suami dari XS
} 
kebutuhan rumah tangga dan juga kebutuhan sekolah, yang pada akhirnya tindakan yang dilakukan suami adalah dengan mencaci dan melakukan pukulan kepada sang istri; (3) kurangnya komunikasi yang baik antara suami dan istri (tampak dari penjelasan ibu XS dan bapak AS) yang mengakibatkan suami merasa tidak dihargai sebagai pemimpin dalam rumah tangga. Faktor lain yang ditemukan penulis dari lapangan adalah adanya kesalahpahaman suami dalam mengartikan firman Tuhan tentang tugas seorang istri yang harus tunduk kepada suami (bd. Ef. 5:22-33). Situasi ini tampak dari pernyataan bapak ST dan BS bahwa tindakan kekerasan yang mereka lakukan adalah hal yang wajar supaya istri mereka tunduk dan mematuhi perintah mereka.

Bentuk kekerasan yang dialami ibu rumah tangga di desa Onantukka adalah kekerasan fisik dan psikis. Kekerasan fisik berupa pukulan yang mengakibatkan istri cedera dibagian tubuhnya. Secara langsung pukulan yang dialami akan mengakibatkan rasa takut dan trauma terhadap perlakuan suami atau disebut juga dengan kekerasan psikis. Kekerasan psikis lainnya adalah cacian yang dilontarkan oleh suami terhadap istri.

${ }^{17}$ Cynthia Nathania Setiawan, Sigit Kirana Lintang Bhima, and Tuntas Dhanardhono, "Faktor-Faktor Yang Memengaruhi Kejadian Kekerasan Dalam Rumah Tangga Dan Pelaporan Pada Pihak
Meskipun terjadi tindak KRDT terhadap beberapa ibu rumah tangga di desa Onantukka, namun situasi tersebut tidak pernah dilaporkan kepada pihak yang berwajib. Hal ini disebabkan oleh pemahaman mereka yang masih menganggap bahwa kekerasan dalam rumah tangga khususnya yang dilakukan oleh suaminya adalah persoalan yang sangat privat dan merupakan hailaon bolon (aib) dalam keluarga apabila diketahui oleh orang lain. Hal ini senada dengan penelitian yang dilakukan oleh Cynthia menjelaskan bahwa faktor yang menghambat korban kekerasan untuk melaporkan situasi yang mereka alami adalah faktor psikologis berupa ancaman dari suami, kurangnya akses informasi, dan berusaha untuk menjaga nama baik keluarga. ${ }^{17}$

\section{Pelayanan Pastoral sebagai Upaya Pencegahan dan Penanganan KDRT}

Informasi yang didapatkan dari kepala desa di Onantukka bahwa kasus KDRT tidak akan pernah ditangani apabila tidak ada korban, khususnya ibu rumah tangga, yang melaporkan tindakan tersebut. Kemudian apabila ada korban yang melaporkan tindakan kekerasan yang terjadi, maka upaya yang dilakukan adalah menco-

Kepolisian," Jurnal Kedokteran Diponegoro 7, no. 1 (2018): 127-139, accessed March 5, 2020, https://ejournal3.undip.ac.id/index.php/medico/artic le/view/19356. 
ba melakukan komunikasi dengan keluarga khususnya pelaku dan korban, dan berusaha untuk mendamaikan serta memberikan bimbingan kepada keluarga dengan cara memberitahukan sanksi/ hukuman yang akan dijalani oleh pelaku KDRT. Bimbingan yang diberikan oleh aparat desa tersebut tentunya tidak menjamin kekerasan yang dialami ibu rumah tangga berhenti. Sementara, apabila kasus tersebut dibawa ke jalur hukum/ polisi, istri/ korban tidak bersedia demi menjaga perasaan anakanak. ${ }^{18}$ Sedangkan untuk mencegah KDRT, ibu NS, sebagai Ketua Tim Pembina Pemberdayaan Kesejahteraan Keluarga, berusaha untuk memberikan bimbingan yang memuat materi tentang keharmonisan keluarga. Hal ini sesuai dengan program PKK bagian kedua yaitu melaksanakan kegiatan penyuluhan kepada rumah tangga yang mencakup kegiatan bimbingan, motivasi dalam upaya mencapai keluarga sejahtera. ${ }^{19}$

Berdasarkan keterangan di atas, penulis melihat bahwa kasus kekerasan yang dialami oleh ibu rumah tangga tidak dapat dijangkau oleh pemerintah setempat. Oleh karena itu gereja penting untuk mengambil peran dalam penanganan kasus kekerasan

\footnotetext{
${ }^{18}$ Wawancara dengan Duce Warnek sebagai kepala desa Onantukka yang pernah menangani kasus kekerasan dalam rumah tangga.

19 Arsip (Laporan Kepala Desa Onantukka dalam Rangka Memonitoring Desa Percontohan PKK tahun 2016.
}

dalam rumah tangga yang terjadi di Onantukka khususnya 5 kasus kekerasan yang dialami ibu rumah tangga. E. G. Homrighausen, sebagaimana dikutip oleh Andreas Soewarno, menjelaskan bahwa salah satu tugas gereja adalah untuk menggembalakan kawanan domba Tuhan dengan perkunjungan rumah tangga berupa pelayanan pastoral. ${ }^{20}$ Pelayanan dinyatakan dengan istilah service, seperti dalam Efesus $4: 12$, "...for the equipping of the saints for the work of service to the building up of the body of Christ" (NASV). Service identik dengan pelayanan yang dilakukan oleh seorang diakonos/ hamba/ pelayan. Perjanjian Baru menyebutkan pelayanan adalah memenuhi keseluruhan kebutuhan orang untuk bisa menguatkan orang yang lebih membutuhkan dalam iman. ${ }^{21}$

Yakub Susabda mendefinisikan pastoral sebagai percakapan terapeutik antara konselor (pastor/ pendeta) dengan konseli/ kliennya, dimana konselor mencoba membimbing konselinya ke dalam suasana percakapan konseling yang ideal (condusive atmosphere) yang memungkinkan konseli tersebut dapat mengenal dan mengerti apa yang sedang terjadi dalam dirinya (self

\footnotetext{
${ }^{20}$ Andreas Soewarno, Pastoral Konseling; Manfaat Dan Penerapannya Untuk Pelayanan Masa Kini (Yogyakarta: Fire Publisher, 2012), 10-11.

${ }^{21}$ Sari Asi Situmorang, "Peranan Diakones Dalam Kehidupan Masyarakat Parongil (Sebuah Studi Kasus)" (Sekolah Tinggi Diakones HKBP, 2017), 19.
} 
awareness), persoalan yang sedang ia hadapi, kondisi hidupnya, dan mengapa ia merespon semua itu dengan pola pikir, perasaan dan sikap tertentu. ${ }^{22}$ Selanjutnya, J.L. Ch. Abineno, sebagaimana dikutip oleh Andreas Soewarno, mengemukakan bahwa pelayanan pastoral, yang dilakukan oleh pastor, mengandung unsur pemeliharaan jiwa yang berupa percakapan antara dua orang (gembala dan yang digembalakan). ${ }^{23}$ Berdasarkan beberapa pengertian tersebut, penulis mendefinisikan bahwa pelayanan pastoral merupakan pelayanan yang dilakukan oleh seorang pastor atau pun pendeta atau pun seorang hamba/ pelayan Tuhan berupa perkunjungan dan penggembalaan terhadap jemaat yang mana di dalamnya memuat unsur percakapan yang dapat membantu jemaat yang dikunjungi atau dilayani dapat memahami masalah yang sedang dialami.

Kasus kekerasan yang dialami oleh ibu rumah tangga di desa Onantukka tidak dapat ditangani hanya dengan program pemerintah setempat saja. Hal ini disebabkan korban sendiri kurang terbuka untuk menceritakan hal yang sesungguhnya terhadap pemerintah setempat untuk ditindaklanjuti secara hukum. Di sisi lain, korban menganggap situasi tersebut adalah perso-

22 Yakub B. Susabda, Konseling Pastoral (Jakarta: BPK Gunung Mulia, 2014), 6.

23 Soewarno, Pastoral Konseling; Manfaat Dan Penerapannya Untuk Pelayanan Masa Kini, 12. alan pribadi yang tidak perlu diketahui oleh pihak yang berwajib. Oleh karena itu, gereja harus hadir untuk melakukan pelayanan bagi mereka yang mengalami kekerasan dalam rumah tangga. Hal yang dilakukan gereja adalah sebagaimana yang telah dikemukakan dalam teori yang telah disampaikan yaitu dengan melakukan pelayanan pastoral. Sebelum melakukan pelayanan pastoral setidaknya pelayan sudah memiliki keterampilan dasar untuk melakukan palayanan kepada jemaat. Totok Wiryasaputra menawarkan beberapa keterampilan yang harus dimiliki seorang konselor yaitu mendengarkan dengan empati, memperjelas persoalan yang dilayani, memantulkan kembali persoalan ataupun pernyataan yang dilayani, menafsir yang bertujuan untuk menolong konseli yang dilayani menghayati krisis kehidupannya, mengarahkan konseli ketika dalam melakukan percakapan, memusatkan, meringkas, memberi informasi, mengajukan pertanyaan dan menantang. ${ }^{24}$

Berdasarkan keterangan dari pendeta dan penatua yang ada di gereja HKBP Onantukka, pelayanan pastoral telah dilakukan dengan menerapkan beberapa teknik keterampilan yang dikemukakan Totok seperti mendengarkan secara empati, mem-

24 Totok S. Wiryasaputra, Pengantar Konseling Pastoral (Yogyakarta: Diandra Pustaka Indonesia, 2014), 138. 
perjelas persoalan yang dialami dan memberikan informasi berupa pemahaman akan firman Tuhan dalam kehidupan berumah tangga kepada jemaat yang dikunjungi. Pelayanan ini diselenggarakan sesuai dengan tugas panggilan gereja. Tujuan dari perkunjungan ini adalah untuk mengajak jemaat untuk tetap memercayai Kristus sebagai Juruselamat, memberikan bimbingan kepada rumah tangga yang jarang mengikuti persekutuan dalam gereja. Tujuan lain dari perkunjungan ini adalah untuk mengetahui permasalahan yang sedang dialami jemaat sehingga diberikan penghiburan dan penguatan. Di sisi lain, gereja juga memberikan pelayanan bagi mereka yang mengalami kekerasan dalam rumah tangga. Pelayanan pastoral yang dilakukan adalah berupa perkunjungan rumah tangga yang diselenggarakan satu kali dalam satu minggu. Sebelum memulai percakapan dengan jemaat yang dikunjungi selalu dibuka dengan nyanyi dan doa bersama, selanjutnya diberikan kesempatan bagi mereka untuk menceritakan pergumulan yang terjadi dalam keluarganya. Hal tersebut merupakan salah satu upaya yang dilakukan gereja untuk menangani kekerasan dalam rumah tangga yang terjadi di desa Onantukka kecamatan Sipahutar.

${ }^{25}$ Wawancara dengan Pdt. Bonar Sitorus sebagai pemimpin gereja HKBP dan salah satu Penatua
Dari lima kasus kekerasan yang terjadi di desa Onantukka, ibu XS dan suaminya AS yang yang benar-benar mengalami pemulihan dalam rumah tangganya. Situasi ini terlihat dari keadaan keluarga XS dan AS yang sudah saling terbuka antara satu dengan yang lain khususnya dalam hal perekonomian. Pemulihan dapat terwujud bagi ibu XS dan keluarganya karena pelayanan pastoral yang dilakukan gereja secara rutin dan terjadwal dilakukan dan karena korban yang mengalami kekerasan dalam rumah tangga serta keluarganya juga memiliki kerinduan untuk menciptakan keluarga yang harmonis. Sementara untuk kasus kekerasan yang lain belum sepenuhnya istri dan suami mau berdamai. ${ }^{25}$

Berdasarkan pemaparan di atas, tampak dengan jelas bahwa pelayanan pastoral telah diterapkan bagi ibu yang mengalami kekerasan dalam rumah tangga sebagaimana dengan tugas panggilan gereja. Satu hal yang menarik adalah penulis melihat bahwa pelayanan pastoral tidak akan dapat berjalan dengan baik apabila tidak ada kerjasama antara pelayan dan yang dilayani. Hal ini terlihat dari beberapa kasus kekerasan yang belum mengalami pemulihan dalam rumah tangganya. Dengan situasi tersebut seorang pelayan atau siapa pun yang ditugaskan oleh gereja dalam mela-

gereja yang terlibat dalam penanganan kekerasan dalam rumah tangga. 
kukan pelayanan pastoral perlu semakin membenahi diri dalam melakukan pelayanan. Misalnya semakin meningkatkan pemahaman tentang firman Tuhan sebagai modal untuk melakukan pelayanan pastoral bagi mereka yang salah paham tentang firman Tuhan tentang "istri tunduk kepada suami” (pengalaman ibu AS dan SS). Di sisi lain, pelayan perlu memiliki sifat-sifat sebagai pelayan yang ditetapkan dalam 1 Timotius 3:1-13, yang diantaranya memiliki reputasi yang baik, sehingga jemaat yang dilayani memercayai pelayannya ketika melakukan pelayanan pastoral dari gereja.

\section{KESIMPULAN}

Persoalan kekerasan dalam rumah tangga tidak cukup ditangani oleh pemerintah atau oleh aparat yang berwajib saja. Hal tersebut oleh karena persoalan tersebut terjadi dalam domain privat, yang seringkali dianggap menimbulkan aib apabila diketahui oleh publik, atau juga dianggap akan membawa dampak lainnya bagi anak misalnya. Dengan demikin, gereja wajib berperan melalui pelayanan pastoralnya untuk menyelesaikan persoalan KDRT. Pelayanan pastoral dirasa lebih efektif karena tidak membuka masalah ke publik, namun memberikan kesempatan kepada keluarga tersebut mengutarakan permasalahannya secara terbuka kepada pendeta atau diaken untuk kemudian mencari solusi terbaik sesuai dengan ajaran Alkitab. Hasilnya yang dicapai adalah terwujudnya perdamaian dari keduabelah pihak, suami dan istri.

\section{DAFTAR PUSTAKA}

Creswell, John W. Research Design: Pendekatan Kualitatif, Kuantitatif, Dan Mixed. Yogyakarta: Pustaka Pelajar, 2012.

Fajrini, Fini, Rr Arum Ariasih, and Noor Latifah A. "Determinan Sikap Tindak Kekerasan Dalam Rumah Tangga Di Provinsi Banten." Aspirasi: Jurnal Masalah-Masalah Sosial 9, no. 2 (2018): 173-189. Accessed March 5, 2020.

http://jurnal.dpr.go.id/index.php/aspir asi/article/view/1113.

Gultom, Maidin. Perlindungan Hukum Terhadap Anak Dan Perempuan. Bandung: Refika Aditama, 2012.

Indah Susanty, Dewi, and Nur Julqurniati. "Kekerasan Terhadap Perempuan Dalam Rumah Tangga Di Flores Timur." Sosio konsepsia 8, no. 2 (July 16, 2019): 139-156.

Murniati, A. Nunuk Prasetyo. Gerakan Anti Kekerasan Perempuan. Yogyakarta: Kanisius, 1998.

Muttaqin, M. Asasul, Ali Murtadho, and Anila Umriana. "Bimbingan Konseling Bagi Perempuan Korban Kekerasan Dalam Rumah Tangga Di Lrc-Kjham Semarang." Sawwa: Jurnal Studi Gender 11, no. 2 (June 12, 2017): 177.

Ngir, Desefention W. 10 Kebutuhan Utama Dalam Pernikahan. Bandung: Kalam Hidup, 2014. 
Ramadani, Mery, and Fitri Yuliani. "Kekerasan Dalam Rumah Tangga (KDRT) Sebagai Salah Satu Isu Kesehatan Masyarakat Secara Global." Jurnal Kesehatan Masyarakat Andalas 9, no. 2 (August 30, 2017): 80.

Ramadhan, Rendi Amanda, and Nurhamlin. "Pengaruh Kekerasan Dalam Rumah Tangga (KDRT) Terhadap Tingkat Keharmonisan Dalam Keluarga Di Kelurahan Umban Sari Kecamatan Rumbai Kota Pekanbaru." Jurnal Online Mahasiswa (JOM) Bidang Ilmu Sosial dan Ilmu Politik 5, no. 1 (2018): 1-15. Accessed March 3, 2020.

https://jom.unri.ac.id/index.php/JOM FSIP/article/view/17259.

Setiawan, Cynthia Nathania, Sigit Kirana Lintang Bhima, and Tuntas Dhanardhono. "Faktor-Faktor Yang Memengaruhi Kejadian Kekerasan Dalam Rumah Tangga Dan Pelaporan
Pada Pihak Kepolisian." Jurnal Kedokteran Diponegoro 7, no. 1 (2018): 127-139. Accessed March 5, 2020.

https://ejournal3.undip.ac.id/index.ph p/medico/article/view/19356.

Situmorang, Sari Asi. "Peranan Diakones Dalam Kehidupan Masyarakat Parongil (Sebuah Studi Kasus)." Sekolah Tinggi Diakones HKBP, 2017.

Soewarno, Andreas. Pastoral Konseling; Manfaat Dan Penerapannya Untuk Pelayanan Masa Kini. Yogyakarta: Fire Publisher, 2012.

Suryati. Kekerasan Dalam Rumah Tangga. Parapat: KSPPM, 2013.

Susabda, Yakub B. Konseling Pastoral. Jakarta: BPK Gunung Mulia, 2014.

Wiryasaputra, Totok S. Pengantar Konseling Pastoral. Yogyakarta: Diandra Pustaka Indonesia, 2014. 